\title{
Some Phonetic Features of Elbasanisht
}

\author{
Manola Myrta \\ "Aleksander Moisiu" University, Durres \\ E-mail: Manola.myrta@yahoo.com
}

\section{Doi:10.5901/ajis.2012.v2n4p189}

\section{Abstract.}

A number of linguistic features characterize each language, or a group of dialects. Elbasanisht, which belongs to the group of dialects of Middle Albania and is included in the southern Gheg, represents itself in a set of common features of its group, but with some other specific features. How are represented these linguistic features of Elbasanisht nowadays? Has the educational and cultural development of the city influenced the linguistic development and change?This paper aims to address some of the general occurrences of Elbasanisht , focused only on the phonetic aspect. Based on the study of a variety of different documents written in this language and also on a wide range of interviews conducted with individuals of different generations, this paper will address how is represented this language from a phonetic aspect nowadays, compared to previous decades. It will also treat the occurrence that includes vowel and consonant system. This paper will help all researchers, who are interested in phonetic changes that a language undergoes in the course of time, under the influence of overall social development.

Keywords: Elbasanishtja, phonetic features, the course of time, social development, language change.

\section{Introduction}

Language is a "living organism" so it is in a continue evolution. Causes leading to the variability of language are of different nature: diachronic and synchronic. However, cooperating, these reasons are associated with a number of changes in the language system, changes that affect all its systems.

Elbasanisht owns a number of phonetic features, as well as other dialects of the North. In its present state, we observe that it retains well a wide range of its phonetic features, while it is trying to lose another part of them (localized as lexical fund of speakers aged over 80 years). What stands out most in this language is that some of its phonetic features have ceased to exist. To present the findings we will focus on the system related to the changes of vowels, vowel groups and consonants system.

\section{Vowel system}

In Elbasanisht, as asserted by Xheladin Gosturani (1983) " the vowel -ë -is preserved better than in all other dialects of the North, it is also preserved in positions where Gheg has completely reduced it "(p.92). Despite this vowel preserving in different positions, we note some phonetic cases in which, this vowel is completely reduced in everyday speech:

a) The vowel-ë-has fallen in the end position in nominal and verbal system: buk,(bread), lek(money), rrug(street), dor(hand), sall(room), pjes(part), makin(car), daj(uncle), gërshan(scissors), tavolin(table), dark(dinner), shkall(stairs), koh(time), djal(boy), dram, (play,) syt(eyes), grat( women), dit( day), e shtun(Saturday), shpin(back), bajm(bëjmë), (do)vem(go), din)know), ta lam(ta lëmë)(let it ), humt (humbtë)(lost), lënoft, (suffer),lujm(play), qajn(cry).

b) It is a feature presented also in the adjectives and adverbs: e gjat(long), e gjan(wide), e mir(good), $i$ mir(good), e trash(thick), e nalt(high), t'verdh(yellow), t'holl(thin), t'bardh(white), përjasht(outside), 
ktu(here), përpjet(forever), shum(much), posht(under), bashk(together), mir(well), prap(again), matan(over), , mat'here(now), kshu (so).

c) In the factual material collected, we have found the lack of vowel-ë-in the end position of pronouns, numerals, and prepositions:

- This feature occurs in different types of pronouns, mainly to the personal pronoun in first person singular, in nominative case: un;(I), personal pronoun: jon ,ton (our), some demonstrative pronouns: kët(gja) (this thing), m'at (çast)(at that moment), kto((these), ksaj(this), ktyre(thse), or indefinite pronoun: $t^{\prime}$ gjith(all).

- There is also a lack of this vowel in numerals: gjasht(six), shtat(seven), pes(five), tet/eight), dhjet(ten), gjashmëdhjet/sixteen), dymëdhjet(twelve), pesdhjet(fifty), pest e pes(fifty five).

- In some adverbs of place used as prepositions rranx (murit)(near the wall), përball (oxhakut) (in front of the firewall), përball (ktyne)(in front of these), përball (atyne)( in front of those), matan rrugës(opposite the street), posht (ktyne)(under these), rranx (murit) (next to the wall).

- In Elbasanisht the vowel-ë-has significant decreases even in the pre-stressed position: : shpis (house), i vllai( brother), gzim(happiness), lartsia(height), hapsina(space), mjeksor(medical), knaqsi(enjoyment).

According to XH. Gosturani (1983) this feature is present mainly to people over 50 years . He sees this occurrence especially present in "the older generation (p. 92). From the study of the data gathered this feature remains involved in the same stretch.

In Elbasanisht, as different researchers have noticed, is preserved the trend of changing the vowel - ëinto other vowels. During our review, we found the following transformations:

a) The typical replacement of the sound system of Gheg dialect and the southern group (Gjinari, Shkurtaj, 2003, f.187) where Elbasanisht is included, we find the use of nasal vowel- â- instead of the stressed vowel -ë-. This feature finds extent to:

- Nouns: gjânsi(width), gjâna(a thing), gjânat(things), kamës(leg), nânë(mother), nândor(November), rândësi(importance), në kâmbë(on foot), ândërr(dream), e hânë(Mondey), dhândri( groom), zâ(sound), dhâmë(teeth), amëlcinât(swets) .

- Adjectives: e gjân(wide), e rân(heavy), e zân(busy), e dhânë (dhënë)(given).

- Pronouns: (të ritë) tand(yours), njâni-tjetrit(each other), njâni(somebody).

- Numerals: nânqin(nine hundred), nândhit(ninety), nân(nine).

- Verbs: âsht(is), bâni(make), u bâ(do), bâhej(did), kan me bâmë(have done), t’i zânë(catch), dâmtue(damage), nârrohesh(change), po i lâ( let it), t’i zân(let's catch) (kanë) bâ(have done), bâmë (bëmë)( did), për të më dhânë( give me).

b) A typical feature is the replacement of final stressed vowel -ë- with the vowel-â -, i- in the words: asgja(nothing), asnji(nobady), ndonji(somebody), nenji(anybody), gjithnji(forever), përgjithnji(forever).

It must be said that we find a wide range of usage of the form" una ", (I) "që asht aqë e njoftun në Elbasan..." (That is well known in Elbasan ...). (Çeliku, 1980, p. 210). The personal pronoun I derived from this feature, as Çeliku claimed:"... in Southeast Gheg dialect the most used form of "una" instead of "un..." (p.19), especially in the elderly generation speech: erdha una(I'm here), fleta una(I slept), e hudhësh una(I have thrown it), una e priç(I have broken it), i mlodha una(I have picked them up), sun bzaja una,(I could not speak), sun ti i flisja una(I coud not say a word).

This substitution occurs also in the word "për krahish "(from shoulders), in which this vowel is found in the post stress position. The example and this feature is present at the age of 80 years and it does not exist in new generation. We can already consider as a substitute that may have had a wider extent in the past decades, but today, in an unstressed position it can be regarded as a consolidated variable in terms of using the vowel- ë-. We find the forms: e kapi për krahësh(catch from the shoulders), nga krahët (from shoulders), prej krahve(from shoulders). 
c) Replacing in some words of vowel-ë- with the vowel-u-, a phenomenon that today is quite limited not only in the use of generations, but also in some examples of words. This shift is observed only in people over 50 years and occurs in words: pullamë(hand), numur(number), pullumat(pigeons), numuroj,(to count) numurim(murmur).

Besides replacing of the vowel-vowel-ë with other vowels, we notice the replacement of other vowels:

1. The replacement of the vowel -a-with the vowel -0-: voj(oil), vorr( grave) kishte vojt(had gone), patën vojt(they had gone) .

This feature is present, generally in people over 50 years, while common in this language and in this age group, is usage of the forms with the nasal â: vâj(oil), vârr.

2. A feature of the Elbasanisht is the replacement of vowel--i- to the vowel-y-: krypë(salt), fyshek (cartridge), qylym(carpet), gjylpan(needle). This feature is generally observed in the speech of old generation, while in the young generation; it is almost consolidated thanks to the continuous action of the standard language.

3. A feature already significantly restricted in use, constitutes the replacement of the vowel--0- into the vowel-u-.This occurs exactly in words, ‘komplet' 'complete` which in the age group over 80 years appears in the form: 'kumplet (e gjitha, e tëra)(whole): do pritesh manga kumplet( the sleeve should be cut), kumplet gjanat(the whole things).

4. Restricted mainly in older generations and especially focused on verbal system, we find today in Elbasanisht the replacement of the vowel -0- by the vowel -u-. M. Çeliku (1968) considers this phenomenon as limited in some words like in 'gumar '(donkey) (p.123-135). In the factual material gathered, we have seen this feature especially spread in the age group over 70 years and focused on verbal system: mur (mori)(take), murën (morën)(they take), murëm (we take), dul (doli) (go out), (dulën (dolën)(they go out).

Gj. Pekmezi in his study of Elbasanisht has noted that " in Elbasan before the stressed syllable the vowel -0-, is replaced by the vowel - a-: tapus(bun), matak (yearling) ..." (Çeliku 1968, p.123-135). M. Çeliku has also written for the same feature, who approves and considers absolutely right 'It is true that in Elbasan the vowel -0-changes to - a- in some cases (dallap, (wordrobe),damatje (tomato), aborr (garden) However, this should not be generalized" (Çeliku 1968, p.123-135). From observations made we can affirm that the mentioned examples that demonstrate this feature are still present in Elbasanisht, but localized mainly in old age, over 70 years. Listening to this generation, we still find conspicuous words like: tapuz, matak, beside the words dallap(wardrobe), aborr(garden).

5. We find the change of unstressed vowel -u- in -h-:kukëll(doll), popëll(people), vetëll(eyebrowns) ect. In his study of the vowel system of Elbasanisht, Xh.. Gosturani (1983) states: " Especially the elderly generation feature occurs when the vowel was found in proton positions: bëllic(bull), gërmac(throat), kënor(crown), këllonte(drain), e mëloi( covered), mënohet (try), mësteqe (moustache), pëno( work), përte:k,(perch), m`rregëlloshin(mend), e zbëlojm (discover)"( p.93).

Today this feature is still present, but with rarely cases. We can encounter words like gërmac(throat), mësteqe (moustache), zbëlon (discover).

While the words: kënor(crown), mënohet,(try), mëloi(cover) occur respectively: kunor(crown), munohet,(try), mloi(cover). So, obviously, we have a reversal of the position of the vowel-u-which has strengthened its presence in these age groups.

6. The feature is present when the word during flexion takes forms in the cases when -ë- is in a position semi postonic, and is reduced to zero (p.93): poplli (people), t'jera rreglla(other rules), ke vetlla.(have eyebrows)

7. Even more reduced is the change of the vowel-u- in the closed vowel-o-, a feature which Xh.Gosturani (1983) considers located in the very elderly age (p.94). We can say that such a change can be found today only at the age of 80 years.

8. We also find the changes of the unstressed vowel-i- in -ë- and-y-, vowel -e- in -i-, vowel -0- in -aRegarding the transfer of vowel -y- in -u-, in the word true:z (table) (Gosturani 1983, p.94), it must 
be said that today, this form is not found even in the old speakers .In this age group we find the word tavolinë (table).

Similar to the above feature is the transfer of the vowel-o- in -u-localized in several subjects over 70 years (Gosturani 1983, p.95). This feature occurs today with the consolidation and the strengthening position of the vowel-0-: govat (washtub), gomar (donkey).

\section{Vowel groups}

In Elbasanisht, we find the monophthongal occurrence of vowel groups ie, ue, ua, uo,ye. Gosturani (1968) states that, " Today in Elbasan do not exist groups like, ue/ua, uo/ie, ye. They are fully monophthongal in all positions, even according to Pekmezi "we find the occurrence of the group vowel ua in Elbasan. According to Nahingal that in Elbasan does not exist monophthong feature, because the second part is still pronounced, but with a half diphthongized vowel (duër, diëll), (the hand, the sun ), but these may be true when they visited Elbasan 80 years ago, it was enough time to bring the sound development "( p. 95).

During the study with different participants, we can say that this occurrence is still present today.

1. The group ue / ue is a monophthong in vowel-u-at in position of the word: msus(teacher), gruja(woman), muj(month), i huj(foreigner), thuj(say), msun(learn), kujtum(believe), konsultum(consult), shkruj(write), vujte (suffering), thush (I say), qush(call), duje(love), luje(play) .

2. Obviously, this feature affects the nominal, verbal and adjectival system, it should be noted that it is widely spread in the verbal system, and finds stretch in different ways to the verb as in the indicative subjunctive and imperative mood,

3. The group -ie-is monophthong also in different positions, dilli(sun) qill(sky), milli(flour) (e) thyme (broken), trishtushme(sad), bim (fall) etc.

We find in the same positions, the group-ye-which is monophthong in vowel-y: kryt(head),fylli (flute), thyn(break), lyn(paint), gënjyn(lie) etc.

However, despite the high density and spread of this feature, we have seen in some cases, the presence of full vowel groups even to an old age, as in the words: duen(want), numurueme(counted), i tërbue(furious), papunuemi(unemployed).

\section{Consonantal system}

Elbasanisht is characterized by a series of transformation of consonantal system. During the study of the linguistic features of this language, we have noticed these transformations of consonantal system:

1. The substitution of consonant $-r$ - by- the consonant $-n-$. This feature is mainly found in the nominal, pronominal and verbal system:, emën, emni(name), femën, femën, femna, femnavet(female), pluhun(dust), dimën(winter), gërshan(scissors), gjansi(width), pleqni(elderly), bojnash(paint), fëmini(childhood), pasuni(welth), dhimsuni(compassion), dashuni(love), kushurinat(cousins), dituni(knowedge), kunorë(crown); ktyne(these), atyne(those), njana-tjetrës(each other), vuna(put), bana (make), prune(bring), hyni (enter),zuna, zuni(catch).

2. In Elbasanisht occurs the feature of replacement of the consonant -h- by -f- mainly in the verbal system: njef, njifte, njifesh, njifeshe(recognise), shof, shef, shif, shifja, shifje(see), nrof (warm up).

3. Another feature are the vocal consonant phonemes in final position, are deafen in their dependents: $\mathrm{d}>\mathrm{t}, \mathrm{g}>\mathrm{k}, \mathrm{s}>\mathrm{z}$. dh> th: $n^{\prime}$ funt(in the end), $n^{\prime}$ vent(instead of) ment(mind), shtek(path), mezi (hardly), erth(come), mloth(mblodhi)(gathere), loth(tired), zgjeth(choose), derth(derdhi)(spill).

4. A feature not widely spread is the replacement of the consonant $-k-$ by $-q-$. This occurs at the spoken language of age 70 and over, as a result demonstrative pronoun this - kjo comes in the form of qo: quhet qo(it is called), qo e cipmja(this upper side), ni qo ishte ma para(this is the first), ene qo ash (and this is), qo e reja(this new one), qo e mlumja(this covered), qo e martumja(this married one), qo e ndamja,(this divorced). 
5. The same for the proliferation and frequency of use of the above feature is also the replacement of the consonant -s-with-c-.Thanks to this feature the word sipër (on), used as an adverb and a preposition appears in the form cipër : e mlon cipër(covered on), cipër e shkruje(write on), mi patën vu ato cipër(put on), cipër sergjenit(on the cupboard), cipër atij kartonit(on that box).

6. Transfer of the consonant $n j-$ in -j-, in the middle of the words. This feature Xh.Gosturani (1983) sees as used in the whole city of Elbasan: rrâja(root), zojâ(lady), bijâk(twin), dyjâ( world), shqipõja(eagle), shtrêjt(expensive), (p.95). Nowadays this feature is still present, especially in people over 50 years, but the younger ages, under the influence of the standard language, use widely the forms: rrânja(root), zonja(ladies), binjak(twin ).

7. Another typical feature of Elbasanisht is vocalization of consonants $s, s h, p, f, t$ in their vocal depended: z, zh, b, v, d: z’d (I don't know), sonde(probe).

\section{Consonant phoneme groups}

In Elbasanisht, as in all the dialects of the North (Gosturani, 1985, p.79), groups mb, nd, ng, respectively monophthong in consonant phonemes: $\mathrm{m}, \mathrm{n}$. This feature is widespread:

- Nouns : pëllâmë(hand), mlesë (blanket), kâm(foot), plum(bullet), kânil(lamp), miner(sofa), funi(skirt), gjenje(condition), ner(honour), menja(mind), hunët(noses), pernia(god), ven, venet (place, places).

- Adjectives: e myllme(closed), e mlume(vovered), e dame(divided), (gjak) të nrimë( frozen blood).

- Numerals: gjashmëdhjet(sixteen), tremëdhjet(thirteen), njimëdhit(eleven), dymëdhit (twelve), katërmëdhit(fourteen), nanqin(nine hundred), nji mi e nanqin e tritht e nan(one thousand, nine hundred and thirty nine).

- Verbs: musheshin(filled), mashin(carried), mlohesh(covered), përmlidhja(summarizes), mështeteshim( support), shemet( collapse), nërroheshin(change), humi(lost), maroi(finished), mush(fill), noqa(follow), menon(think), nriti(lift), noth(happen), nrihesh(get up).

- Adverbs: përmys( up down), përmrena, mrena(into), knej(around), noiher(sometimes), anej(there).

- Prepositions: nër (ndër) vene t'nryshme,(in different countries), nër ma t'mirët( from the best), nër ma t'bukrat (from the most beautiful), mi çati ( on the roof), mi oxhak( on the fireplace), mi tabaka(on the tray), mi t'gjitha(over all), na gzimi(from the happiness), na ato fmit(from those children), na menja(in the mind), na puna(from work), na Elbasanit(from Elbasan), na turqishtja (from Turkish), na vitet(during the years).

- The feature of transferring groups is studied by linguist Xh.Kosturani(1985), such as -tj-,-dj- in -qand- gj-: qetër(another); qegël(tile); aqe(there), gjath-(cheese), gjegim (burn), dje (yesterday) (p.80). From the studies, we may conclude that today this feature has lost its existence. We conclude that, this old, characteristic feature of Elbasanisht, " the impact of the speech around where the feature occurs "(Gosturani 1985, p.80), nowadays it does not exist and it is not a characteristic feature of middle or old age in the city of Elbasan.

\section{Assimilation and addition of sounds}

1. A widespread phenomenon in Elbasanisht, especially among people over 50 years, is the assimilation of sounds, which leads to the hampering of many words. This feature is present in various parts of speech and we will provide words classified in systems. During the study of the factual material, we have found:

- Nominal system: ship(shqip), rreglla(rules), gjys(gjysmë)(half), (kësaj)(this), knese (të kënduari)(singing), mles ( mbulesë)(blanket), shpia(house), shpin(back), mirmjes(good morning), msim(lesson), njers(people), mjes(morning), vlla(brother), fmi(child), fustan (dress), ko (kohë)(time), prindët(parents), ve (vezë),(eggs), feminine(childhood). 
- Adjectival system: e Içume (released), e mlume, (covered), (misra) t'zi(boiled corns) t'mdhejt,(big), t'bukra(beautiful), i zgjut,(clever).

- Numeral system: pest e gjasht(five and six), pest e pes(five and five), nan(nine), nji mi e nanqin e dhit(one thousand, nine hundred and ten), tetdhit e ca vjeç (over eighty).

- Verbal system: sun(s`mund) (cannot), tiq (tërhiq),(pull), mson (mëson)(learn), mur (mori)(take), ngjo (dëgjo)(listen), e ngjon (hear), leu (born), knojn (sing).

- Adverbial system: ashu(so), mrena(inside), noiher(sometimes), asiher(never), përgjys(half).

2. Beside assimilation feature, there is also the additional sounds feature:

- Epenthesis, which occurs with the epenthetic -j- ( f.80): me lulje qark e përqark(with flowers around), u nritsh herjet(I get up early), dul herjet(go out early), erth herjet(come early), kan flet herjet(sleep early).

- Epenthesis, as a result of which, in Elbasanisht, the demonstrative pronoun that in objective case, appears in atën/aten: $i$ thash për atën( I said for that), $i$ dhash atën (I gave that), atën qi kemi lan (we have left that), aten ma t'voglën (that, the smallest).

As Xh. Gosturani (1985) has written, " in the words fshe:s (broom ) and fshi:j (rub)and in all words derived from them instead of the consonant-f- appears two labial vocal consonant -m-: mëshij, ta mëshijm, t'mëshime, meshes( rub, broom) "(p.80). This feature continues to be present in this language today in the age group over 50 years undergoing another phonetic change: the fall of vowel-ë-from which derives the forms: mshij, it mshijm, mshime (rub).

All the above changes, which affect completely the phonetic system of Elbasanisht, we point out the fact that the language in its entirety, or even a single dialect, cannot avoid variability. The time factor (diachronic aspect), as well as other factors such as education, general social and cultural development of the speakers, etc. (synchronic aspect), imply that package of factors providing a new aspect of language whenever we undertake a research.

\section{References}

Beci, B.,Gjurmimi i të folmeve qendrore të dialektit të Veriut, Studime Filologjike, 2, 1970.

Çeliku, M., E folmja e Dumresë, Buletin USHT 2, 1963.

Çeliku, M., Gegërishtja jugperëndimore, Autoreferat, Instituti i Lartë Pedagogjijk A.Xhuvani, Elbasan, 1980.

Çeliku, M., Mbi grupimin e të folmeve të gegërishtes jugore dhe mbi disa tipare të tyre, Studime Filologjike, 3, 1968.

Gosturani, Xh., Dukuri fonetike në sistemin e zanoreve të së folmes së Elbasanit, Studime Filologjike, 1, 1983.

Gosturani, Xh., Sistemi i bashkëtingëlloreve në të folmen e qytetit të Elbasanit, Studime Filologjike, 2, 1985.

Gjinari, J.,Shkurtaj, Gj., Dialektologjia, Tiranë 2003.

Gjinari, J., Diftongjet ua/ue, ye në të folmet e gjuhës shqipe, Studime Filologjike, 1, 1968.

Gjinari, J., Zanoret hundore të gegërishtes dhe ë-ia e theksuar e toskërishtes, në Studime Filologjike, 3, 1981. 